Case report

\title{
IMMUNE-MEDIATED HEMOLYTIC ANEMIA ASSOCIATED WITH CANDIDATUS MYCOPLASMA HAEMATOPARVUM IN A SPLENECTOMIZED DOG IN ITALY
}

\author{
ZOBBA Rosanna ${ }^{1}$, CORDA Andrea ${ }^{1 *}$, BALLOCCO Isabella ${ }^{1}$, \\ SOTGIU Francesca ${ }^{1}$, ALBERTI Alberto ${ }^{1}$, ANTOGNONI Maria Teresa ${ }^{2}$, \\ PINNA PARPAGLIA Maria Luisa ${ }^{1}$ \\ ${ }^{1}$ Department of Veterinary Medicine, University of Sassari, via Vienna 2, Sassari, Italy \\ ${ }^{2}$ Department of Veterinary Medicine, University of Perugia, via S. Costanzo 4, Perugia, Italy
}

(Received 05 July, Accepted 23 December 2019)

\begin{abstract}
This report describes a case of canine hemotropic mycoplasmasosis by Candidatus Mycoplasma haematoparvum in a dog. A five-year-old splenectomized dog was referred to the Veterinary Teaching Hospital of the University of Sassari with clinical symptoms and laboratory findings compatible with immune-mediated hemolytic anemia. Epicellular bacteria were detected in the erythrocytes by microscopic examination of blood smears. PCR and sequencing were positive for Candidatus Mycoplasma haematoparvum. Treatment with doxycycline, prednisolone and blood transfusion was administered. Several studies have described the molecular prevalence of $M$. hemocanis and Candidatus M. haematoparvum, however there are few clinical reports, especially those describing Candidatus M. haematoparvum infection in dogs, for which only two cases have been reported. To the best of our knowledge this is the first case report of a symptomatic infection caused by Candidatus Mycoplasma haematoparvum in Italy. Hemoplasmosis should be considered as a potential cause of hemolytic anemia in dogs. Following treatment with doxycycline and prednisolone, the clinical signs improved without resolution of infection. This condition was the same at the three-year follow-up.
\end{abstract}

Key words: Candidatus Mycoplasma haematoparvum, Immune-mediated hemolytic anemia, Polymerase chain reaction, Phylogenetic analysis

\section{INTRODUCTION}

Canine hemotropic mycoplasmas (hemoplasmas) are cell wall-deficient bacterial pathogens that attach to the surface of erythrocytes of infected animals. Clinical infections are usually chronic and subclinical in immunocompetent dogs, but may lead to acute signs related to hemolytic anemia following splenectomy, immunosuppression, or concurrent infections [1].

*Corresponding author: e-mail: andreacorda@uniss.it 
Two different species have been recognized in dogs: Mycoplasma hemocanis (Mhc) and Candidatus Mycoplasma haematoparvum (CMhp). Several studies have described the molecular prevalence of $M$. haemocanis and Candidatus M. haematoparvum however there are few clinical reports, especially those describing Candidatus M. haematoparvum infection in dogs, for which only two cases have been reported [2-3].

This report describes the clinical presentation, the use of the correct diagnostic tools and the follow-up of the disease caused by CMhp in a splenectomized dog with immunemediated hemolytic anemia. The aim is to improve the current poor knowledge of canine hemoplasmosis, its pathogenicity, diagnosis, therapy and prognosis.

\section{CASE PRESENTATION}

A five-year-old female Beagle dog, living in Sardinia (Italy), was presented to the Veterinary Teaching Hospital of the University of Sassari. The anamnesis reported depression, asthenia and anorexia for three days. Two months prior to the illness, the dog had been splenectomized due to a perforating wound of the abdomen caused by a wild boar. Vaccinations had been performed regularly up to the second year of life and prophylaxis against ecto- and endoparasites was not constant. Physical examination revealed pale mucous membranes, tachycardia, tachypnea, depression, increased capillary refill time, and massive flea infestation.

The results of the cell blood count and serum biochemical profile included severe macrocytic hypochromic anemia with a marked reticulocytosis, inflammatory leukocytosis characterized by an increase in band neutrophils and lymphocytosis, mild hypoalbuminemia, and increased renal parameters (Table 1). Blood smear examination revealed signs of immune-mediated hemolytic anemia: microagglutination, hypochromia, anisocytosis, polychromasia, Howell-Jolly bodies, leptocytes, nucleated red blood cells (nRBC), and signs of inflammatory response: band neutrophils and activated lymphocytes. The presence of $\mathrm{nRBC}$ was also related to the splenectomized condition. Observation of the blood smear with a $100 \mathrm{X}$ objective highlighted the presence of parasites on the surface of red blood cells, probably belonging to the genus Mycoplasma. These appeared as basophilic, round or rod-shaped structures organized individually or in chains (Figure 1). The presence of IgG-IgM anti-erythrocyte antibodies, detected by cytofluorimetry, and a positive Coombs test confirmed the immune-mediated hemolytic anemia. Abdominal and thoracic ultrasound examination did not show clinically significant abnormalities. Serologic tests (IFAT) against Leishmania infantum, Ehrlichia canis, and Anaplasma phagocytophilum were negative.

DNA was extracted from a blood sample and used in two single PCRs for amplification of a $1429 \mathrm{bp}$ and $232 \mathrm{bp}$ fragment of the 16S rRNA and RNase P gene specific for Mycoplasma spp. The sequenced amplicons, deposited in the GenBank under access numbers MH094850 and MH090015, were closely related to Candidatus Mycoplasma haematoparvum (99\% identity with 100\% coverage). 
Table 1. Hematological and biochemical findings in the dog on the day of the first visit and after 30, 60, 120, and 180 days.

\begin{tabular}{|c|c|c|c|c|c|}
\hline Parameter & to & t30 & t60 & $\mathrm{t} 120$ & t180 \\
\hline $\mathrm{RBC} 10^{6} / \mathrm{ml}(5.5-8.5)$ & 1.56 & 4.73 & 6.03 & 6.81 & 5.95 \\
\hline $\mathrm{Hgb} \mathrm{g} / \mathrm{dl}(12-18)$ & 3.5 & 10.9 & 14.5 & 15.9 & 12.1 \\
\hline Hct $\%(37-55)$ & 14 & 36 & 45 & 49 & 45 \\
\hline MCV fL $(60-77)$ & 92 & 75 & 75 & 71 & 76 \\
\hline $\mathrm{MCH}$ pg $(18.5-30)$ & 22.4 & 23.1 & 24 & 23.3 & 20.3 \\
\hline $\mathrm{MCHC} \mathrm{g} / \mathrm{dl}(30-37.5)$ & 24.4 & 30.8 & 32.1 & 32.6 & 27 \\
\hline Retic $10^{3} / \mathrm{ml}(10-110)$ & 673.9 & 898.7 & 133.6 & 151.8 & nd \\
\hline Nucleated RBC (nRBC/100 WBC) & $7.4 \%$ & nd & nd & nd & $4.5 \%$ \\
\hline Anisocytosis & present & present & nd & nd & present \\
\hline PTL $10^{3} / \mathrm{ml}(175-500)$ & 336 & 980 & 845 & 894 & 504 \\
\hline MPV fL & 10.7 & 8.1 & 8.7 & 5.8 & 7.1 \\
\hline WBC $10^{3} / \mathrm{ml}(5.5-16.9)$ & 19.6 & 6.3 & 8.8 & 7.1 & 13.6 \\
\hline WBCc & 18.2 & & & & \\
\hline Neutroph $10^{3} / \mathrm{ml}(2-12)$ & 7.1 & 4.8 & 5.6 & 4.9 & 9.9 \\
\hline Band neutroph $10^{3} / \mathrm{ml}$ & 3.3 & 0.1 & nd & nd & 0.3 \\
\hline Lymph $10^{3} / \mathrm{ml}(0.5-4.9)$ & 6 & 1 & 1.9 & 1.6 & 2 \\
\hline Monoc $10^{3} / \mathrm{ml}(0.3-2)$ & 1.8 & 0.3 & 0.8 & 0.3 & 1.1 \\
\hline Eosinoph $10^{3} / \mathrm{ml}(0.1-1.5)$ & - & 0.1 & 0.4 & 0.2 & 0.3 \\
\hline Basoph $10^{3} / \mathrm{ml}(0-0.1)$ & - & - & 0.1 & 0.1 & - \\
\hline Tot Prot g/dl $(5.4-7.7)$ & 5.7 & 6.9 & nd & nd & 6.7 \\
\hline $\mathrm{Alb} g / \mathrm{dl}(2.7-4.4)$ & 2.5 & 2.7 & nd & nd & 2.6 \\
\hline Crea mg/dl $(0.4-1.5)$ & 3.7 & 0.5 & nd & nd & 1 \\
\hline $\mathrm{BUN} \mathrm{mg} / \mathrm{dl}(8-30)$ & 349 & 34 & nd & nd & 30 \\
\hline
\end{tabular}

Legend: nd not determined.

LaserCyte Hematology Analyzer (Idexx, The Netherlands); Chemistry Analyzer Catalyst DX (Idexx, The Netherlands).

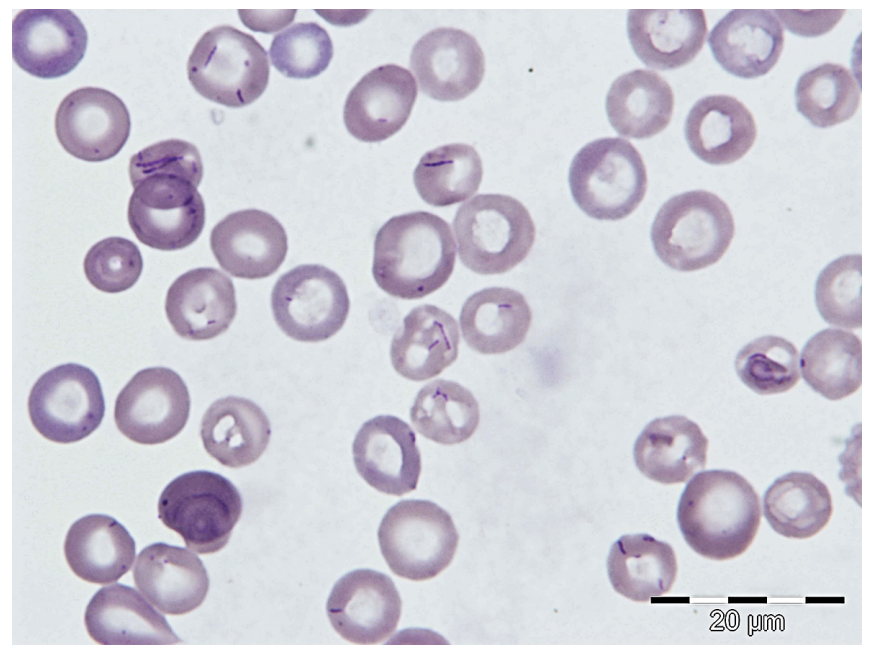

Figure 1. Blood smear revealing the presence of parasites on the surface of red blood cells belonging to the genus Mycoplasma. Rapid Diff Quick stain. 100X objective. 


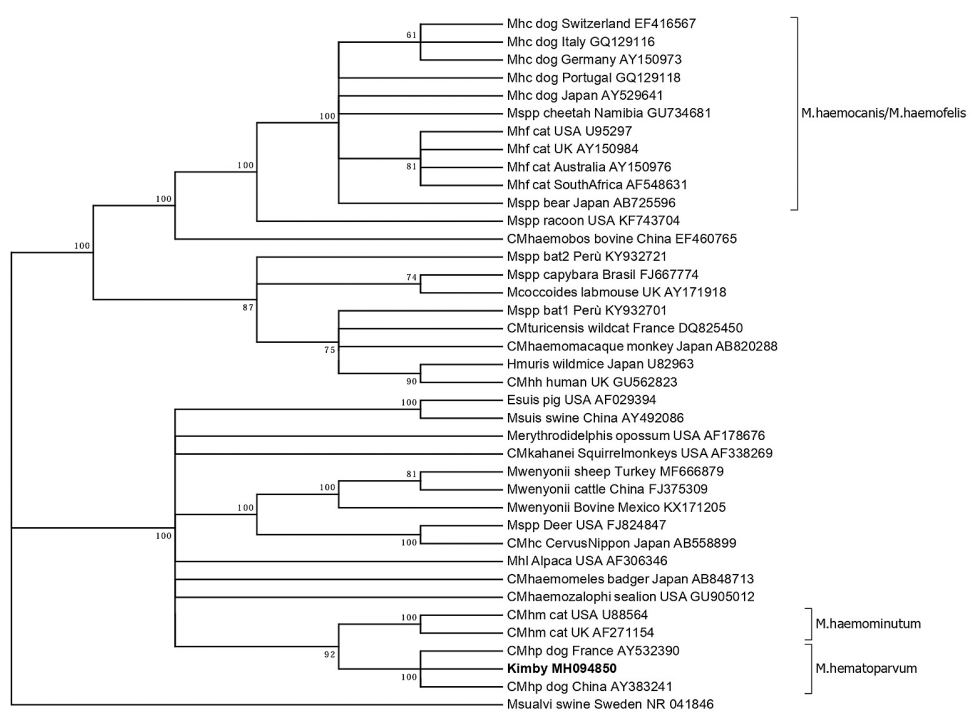

Figure 2. Evolutionary relationships of taxa. 16S rRNA-based phylogenetic analyses of the CMhp identified in the present study and 38 sequences of other hemotropic mycoplasmas. The evolutionary history was inferred using the neighbor -joining method. The optimal tree with the sum of branch lengths $=1.17537978$ is shown. The percentages of replicate trees in which the associated taxa clustered together in the bootstrap test (100 replicates) are shown next to the branches. The evolutionary distances were computed using the LogDet method (TamuraKumar) and are in the units of the number of base substitutions per site. The analysis involved 39 nucleotide sequences. All positions containing gaps and missing data were eliminated. There was a total of 1240 positions in the final dataset. Evolutionary analyses were conducted in MEGA6.

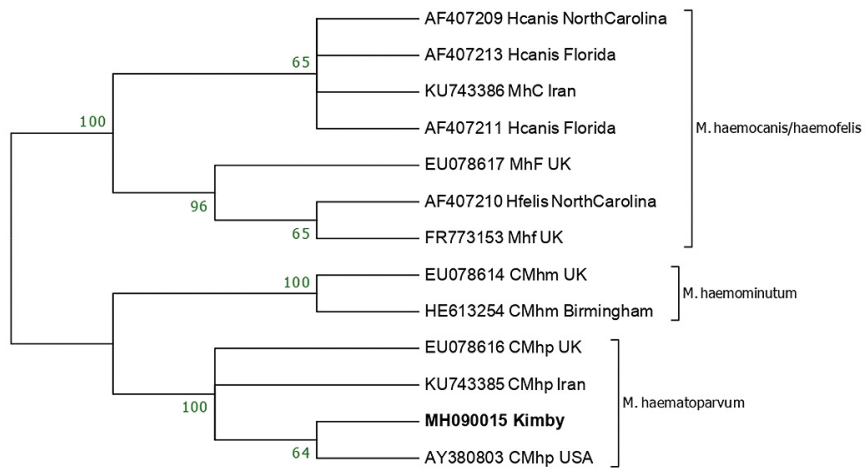

Figure 3. Evolutionary relationships of taxa. rnpB-based phylogenetic analyses of the CMhp identified in the present study and 12 sequences of other feline and canine hemotropic mycoplasmas. The evolutionary history was inferred using the neighbor-joining method. The optimal tree with the sum of branch length $=0.53883531$ is shown. The percentage of replicate trees in which the associated taxa clustered together in the bootstrap test (100 replicates) are shown next to the branches. The evolutionary distances were computed using the LogDet method (Tamura-Kumar) and are in the units of the number of base substitutions per site. The analysis involved 13 nucleotide sequences. All positions containing gaps and missing data were eliminated. There was a total of 171 positions in the final dataset. Evolutionary analyses were conducted in MEGA6. 
Using the ClustalW option of BioEdit [4], a fragment of 1297 bp of the 16S rRNA sequence and the $187 \mathrm{pb}$ sequence of the $\mathrm{rnpB}$ gene determined in this study were aligned with the corresponding region of 38 other mammalian hemotropic mycoplasmas and 12 other canine and feline hemotropic mycoplasmas, respectively, available in the GenBank. Phylogenetic analysis using the neighbor-joining [5] method was conducted with MEGA 6 software [6]. Internal branches of the trees were statistically supported by bootstrapping with 1,000 iterations [7] (Figures 2 and 3).

The dog was treated with doxycycline ( $10 \mathrm{mg} / \mathrm{kg}$ orally every 24 hours for five months) and prednisolone $(2 \mathrm{mg} / \mathrm{kg}$ orally every 24 hours for one month). In order to stabilize the patient, the dog was immediately subjected to blood typing (DEA1.1+), crossmatching and transfusion with $20 \mathrm{ml} / \mathrm{kg}$ of compatible whole blood and fluid therapy with Ringer lactate solution. Following the initiation of therapy, the dog improved clinically, and renal parameters returned to the normal range on the assumption of a pre-renal condition.

On day 60, hematological values were normalized except for thrombocytosis, as a consequence of the splenectomy, and reticulocytosis which was decreased compared to the first day. The persistent reticulocytosis was explained by a compensated anemia, a condition described in immunomediated hemolysis [8]. The microorganisms were no longer detected on blood smears. However, the PCR for Mycoplasma spp, performed 30 and 60 days after diagnosis, was still positive. The therapy was thus prolonged for another three months, after which the patient was still PCR positive, but without symptoms. It was decided to interrupt the antibiotic therapy and to monitor the dog. In the following months the physical examination and blood count were similar to the time of discharge. Three years after the diagnosis of mycoplasmosis, the owner reported that the dog was fine and had no symptoms.

Although several studies on the molecular prevalence of Mhc and CMhp have been described, reports about clinical signs are rare, especially regarding CMhp, for which only two cases have been reported. The first clinical case was described by Sykes et al. in 2004 in a splenectomized dog with hematic alterations caused by a T-cell lymphoproliferative disease in California [2]. Ten years later Sharifiyazdi et al. reported a case of fever, regenerative anemia, leukocytosis, thrombocytosis, and urinary bilirubin, associated with CMhp in a non-splenectomized dog in southern Iran [3].

Phylogenetic analysis of $16 \mathrm{~S}$ rRNA and the rnpB sequence confirmed that our isolate clustered within the CMhp group and was more distantly related to Mhc, similarly to findings by Sykes and Sharifiyazdi [2-3]. However, it is not possible to clinically compare our case and Sykes' report because the clinical signs of his patient were caused by the lymphoproliferative disease and the dog was consequently euthanized.

The laboratory alterations caused by the immune-mediated hemolytic anemia in our dog were similar to the findings observed by Sharifiyazdi, although the latter was not splenectomized. Our case is similar to infections due to M. haemocanis described by other authors: splenectomized patient, hemolytic anemia, progression to a subclinical form, and persistence of PCR positivity after treatment with doxycycline [9-12]. 
To the best of our knowledge, our study is the first report of a symptomatic infection with Candidatus Mycoplasma haematoparvum in Italy. Two previous studies have been reported on the distribution of canine hemotropic mycoplasma infections in Italy. Novacco et al. (2010) reported a prevalence of 5.8\% of CMhp infection in randomly selected dogs from central and southern Italy without clinical signs which were clearly attributable to canine hemoplasma infection. An interesting aspect underlined by these authors is the higher CMhp load found in the splenectomized dog [13]. Ravagnan et al. (2017) found a lower prevalence of CMhp in dogs from northern Italy (1.4\% positivity in dogs from shelters in Padua and Treviso) [14].

Doxycycline is the drug of choice in mycoplasmosis therapy $(5-10 \mathrm{mg} / \mathrm{kg}$ orally every 24 hours for 21 days) [9, 15], however data are not available on its efficacy in CMhp therapy. In our case, doxycycline for five months improved clinical signs with excellent results, however it was interrupted without complete clearance of mycoplasma infection. Despite this, the dog had no recurrence of the disease at the three-year follow-up. This is in line with findings by other authors in a dog with Mhc. The resolution of the clinical disease in dogs treated with a long-term antibiotic therapy could be due to the development of an effective immune response by the dog, which often remains a chronic carrier after clinical signs have resolved [12].

Our patient's clinical recovery implies a good prognosis, but not in terms of resolving the infection. This is a typical report characterized by the transition from an acute form with immune-mediated hemolytic anemia to a subclinical/chronic condition in which the presence of the parasite is not accompanied by any clinical manifestation. In fact, the fluctuating finding of some laboratory alterations, such as piastrinocytosis and nucleated red blood cells, are related to the splenectomy condition.

In our study we confirmed the higher sensitivity of PCR compared to a blood smear. PCR, or quantitative PCR, is the gold standard for the detection of canine hemoplasmas, especially in chronic or subclinical forms or in a follow up, during which there are fewer bacteria [16]. Most non-splenectomized infected dogs without evidence of disease do not have a sufficient number of organisms present in the blood to be recognized during routine blood smear examination [11]. PCR should be used to monitor the exacerbation of chronic infection in dogs undergoing splenectomy or immunosuppressive therapy, and for screening blood donor dogs [9].

In conclusion, this is the first report of a symptomatic infection caused by Candidatus Mycoplasma haematoparvum in a dog in Italy. Our aim was to underline the clinical aspects of the disease and increase the scant bibliography. In addition, our findings underline the need to consider hemoplasma infections among the differential diagnoses in canine immune-mediated hemolytic anemia, particularly in splenectomized or immunosuppressed dogs, and to recommend using PCR for diagnosis and clinical follow-up. 


\section{Acknowledgments}

This case report is part of a larger research project, funded by the Fondazione Banco di Sardegna-2015. The authors would like to thank Marko Lakoseljac and Simona Andreeva for translating the abstract into Serbian.

\section{Authors' contributions}

MLPP, IB, AC and MTA have performed the clinical procedures. RZ, FS and AA have performed laboratory analysis. AA and RZ have performed phylogenetic analysis. RZ, MLPP and AC have been involved in drafting the manuscript or revising it critically for important intellectual content and have given final approval of the final version of the manuscript. All authors read and approved the final manuscript.

\section{Declaration of conflicting interests}

The author(s) declared no potential conflicts of interest with respect to the research, authorship, and/or publication of this article.

\section{REFERENCES}

1. Messick JB: Hemotrophic mycoplasmas (hemoplasmas): a review and new insights into pathogenic potential. Vet Clin Pathol 2004, 33(1):2-13.

2. Sykes JE, Bailiff NL, Ball LM, Foreman O, George JW, Fry MM: Identification of a novel hemotropic mycoplasma in a splenectomized dog with hemic neoplasia. J Am Vet Med Assoc 2004, 224(12):1946-1951.

3. Sharifiyazdi H, Abbaszadeh Hasiri M, Amini AH: Intravascular hemolysis associated with Candidatus Mycoplasma haematoparvum in a non-splenectomized dog in the south region of Iran. Vet Res Forum 2014, 5(3):243-246.

4. Hall TA: BioEdit: a user-friendly biological sequence alignment editor and analysis program for Windows 95/98/NT. Nucleic Acids Symp Ser 1999, 41:95-98.

5. Saitou N, Nei M: The neighbor-joining method: A new method for reconstructing phylogenetic trees. Mol Biol Evol 1987, 4:406-425

6. Tamura K, Stecher G, Peterson D, Filipski A, Kumar S: MEGA6: Molecular Evolutionary Genetics Analysis version 6.0. Mol Biol Evol 2013, 30:2725-2729.

7. Felsenstein J. Confidence limits on phylogenies: An approach using the bootstrap. Evolution 1985, 39:783-791.

8. Mills J: Anemia. In: Ematologia e Medicina Trasfusionale del cane e del gatto (1st ed). Milano, MI: UTET; 2004, 33-46.

9. Brinson JJ, Messick JB: Use of a polymerase chain reaction assay for detection of Haemobartonella canis in a dog. J Am Vet Med Assoc 2001, 218(12):1943-1945.

10. Kemming GI, Messick JB, Enders G, Boros M, Lorenz B, Muenzing S: Mycoplasma haemocanis infection-A kennel disease. Comp Med 2004, 54(4):404-409.

11. Messick JB, Harvey JW: Hemotropic mycoplasmosis (hemobartonellosis). In: Infectious diseases of the dog and cat (4th ed). St Louis, Mo: Saunders Elsevier; 2012, 310-319. 
12. Hulme-Moir KL, Barker EN, Stonelake A, Helps CR, Tasker S: Use of real-time quantitative polymerase chain reaction to monitor antibiotic therapy in a dog with naturally acquired Mycoplasma haemocanis infection. J Vet Diagn Invest 2010, 22(4):582-587.

13. Novacco M, Meli ML, Gentilini F, Marsilio F, Ceci C, Pennisi MG, Lombardo G, Lloret A, Santos L, Carrapiço T, Willi B, Wolf G, Lutz H, Hofmann-Lehmann R: Prevalence and geographical distribution of canine hemotropic mycoplasma infections in Mediterranean countries and analysis of risk factors for infection. Vet Microbiol 2010, 19,142(3-4):276-84.

14. Ravagnan S, Carli E, Piseddu E, Da Rold G, Porcellato E, Zanardello C, Carminato A, Vascellari M, Capelli G: Prevalence and molecular characterization of canine and feline hemotropic mycoplasmas (hemoplasmas) in northern Italy. Parasit Vectors, 2017, 13,10(1):132.

15. Messick JB: New perspectives about Hemotrophic mycoplasma (formerly, Haemobartonella and Eperythrozoon species) infections in dogs and cats. Vet Clin North Am Small Anim Pract 2003, 33(6):1453-1465.

16. Pitorri F, Dell'Orco M, Carmichael N, Barker EN, Hollywood M, Tasker S: Use of realtime quantitative PCR to document successful treatment of Mycoplasma haemocanis infection with doxycycline in a dog. Vet Clin Pathol 2012, 41:493-496.

\title{
IMUNOLOŠKI POSREDOVANA HEMOLITIČKA ANEMIJA UDRUŽENA SA CANDIDATUS MYCOPLASMA HAEMOATOPARVUM KOD SPLENEKTOMISANOG PSA U ITALIJI
}

\author{
ZOBBA Rosanna, CORDA Andrea, BALLOCCO Isabella, SOTGIU Francesca, \\ ALBERTI Alberto, ANTOGNONI Maria Teresa, PINNA PARPAGLIA Maria Luisa
}

Izveštaj opisuje slučaj hemotropne mikoplazmoze psa izazvane Candidatus Mycoplasma haematoparvum. Petogodišnji splenektomirani pas je upućen u Veterinarsku nastavnu bolnicu Univerziteta u Sassariju sa kliničkim simptomima i laboratorijskim nalazima koji su kompatibilni sa imunološki posredovanom hemolitičkom anemijom. Epicelularne bakterije su detektovane na eritrocitima mikroskopskim pregledom razmaza krvi. PCR i sekvenciranje su bili pozitivni za Candidatus Mycoplasma haematoparvum. Izvršen je tretman doksiciklinom, prednisolonom i tranfuzijom krvi. Nekoliko studija opisalo je molekularnu prevalenciju Mycoplasma haemocanis i Candidatus Mycoplasma haematoparvum, ali klinički izveštaji su oskudni, posebno opisujući infekciju sa Micoplasma haematoparvum kod pasa za koju su prijavljena samo dva slučaja. Prema našim saznanjima ovo je je prvi prikaz slučaja simptomatske infekcije uzrokovane Candidatus Mycoplasma haematoparvumom u Italiji. Hemoplazmozu treba posmatrati kao potencijalni uzrok hemolitičke anemije kod pasa. Nakon tretmana doksiciklinom i prednisolonom klinički znaci su se poboljšali bez nestanka infekcije. Stanje je bilo nepromenjeno u tokom naredne tri godine. 